\title{
Effects of shelterwood and site preparation on microclimate and establishment of white spruce seedlings in a boreal mixedwood forest
}

\author{
by Rongzhou Man ${ }^{1}$ and Victor J. Lieffers ${ }^{2}$
}

\begin{abstract}
Microclimate and seedling response of planted white spruce were investigated under four canopy densities (control - a 120year old uncut aspen/white spruce stand, low and high residual densities of shelterwood canopy, and clearcut) and three site preparation treatments in the Lower Foothills of central Alberta. The partial canopy of the shelterwoods had a less extreme environment than the clearcut: higher humidity and soil temperature, lower maximum air temperature and occurrence and severity of night frost, and a light regime that was nearly optimum for height growth of juvenile white spruce. Planted white spruce seedlings had earlier bud break, lower seedling mortality and terminal bud mortality, higher rates of photosynthesis and stomatal conductance, and greater height and diameter increments under shelterwoods than those in either clearcut or control. Site preparation increased soil temperature, decreased seedling mortality and improved growth, especially diameter growth. This study demonstrates how shelterwoods and site preparation can improve the establishment of white spruce. The findings of this study can be applied to the situations where white spruce establishes in the understory.
\end{abstract}

Key words: shelterwood, site preparation, white spruce, seedling response, microclimatic conditions.
Les modifications du microclimat et les réactions des semis d'épinette blanche en plantation ont été étudiées sous quatre densités de couvert forestier (un témoin - un peuplement non perturbé de tremble et d'épinette blanche de 120 ans, un couvert de coupe progressive faible et en hauteur, et une coupe à blanc) et selon trois traitements de préparation du sol dans les Lower Foothills du centre de l'Alberta. Le couvert partiel des coupes progressives constituait un environnement moins extrême que la coupe à blanc: unephlus forte humidité et température du sol, une température maximale de l'air plus faible et moins de cas et d'importance de gel nocturne, et une régime d'ensoleillement près de l'optimal pour la croissance des jeunes plants d'épinette blanche. Les semis d'épinette blanche en plantation ont connu un débourrement plus hâtif, un taux plus faible de mortalité et de mortalité du bourgeon terminal, des taux plus élevés de photosynthèse et de conductivité stomatale, et une plus forte croissance en hauteur et en diamètre sous les coupes progressives que dans les coupes à blanc et pour le témoin. La préparation du sol a fait augmenté la température du sol, diminué la mortalité des semis et amélioré la croissance, surtout la croissance en diamètre. Cette étude démontre comment les coupes progressives et la préparation du sol peuvent améliorer l'établissement de l'épinette blanche. Les résultats de cette étude peuvent être appliqués à des situations où l'épinette blanche s'établit sous couvert.

Mots-clés: coupes progressives, préparation du sol, épinette blanche, réactions des semis, conditions microclimatiques

\section{Introduction}

The slow growth of planted seedlings in the first few years after planting, commonly referred to as planting check, has been widely reported for white spruce (Picea glauca (Moench) Voss) plantations (Mullin 1963, Vyse 1981, Burdett et al. 1984, Nienstaedt and Zasada 1990). At minimum, this slow growth can cause the loss of several growing seasons, but in many cases it can result in plantation failure if heavy beds of vegetation establish quickly and overtop the trees (Eis 1981). Suggested causes for the poor initial establishment of white spruce include excess or deficient soil moisture, excess solar radiation and daytime temperature, summer frosts, low soil temperature, and nutrient deficiency (Mullin 1963, Burdett et al. 1984). Some studies suggest that water stress resulting from low soil moisture and temperature and a high vapour pressure deficit (VPD) is the primary causal factor (Grossnickle 1988, Marsden et al. 1996) limiting the ability of newly planted seedlings to absorb water from soil (Burdett 1990).

Regeneration conditions can be improved by manipulating the forest canopy and ground surface. In shelterwood systems,

\footnotetext{
${ }^{1}$ Alberta Research Council, P.O. Bag 4000, Vegreville, Alberta T9C 1T4. E-mail:man@aec.arc.ab.ca

${ }^{2}$ Dept of Renewable Resources, University of Alberta, Edmonton, Alberta T6G 2E3. E-mail:Victor.Lieffers@ualberta.ca
}

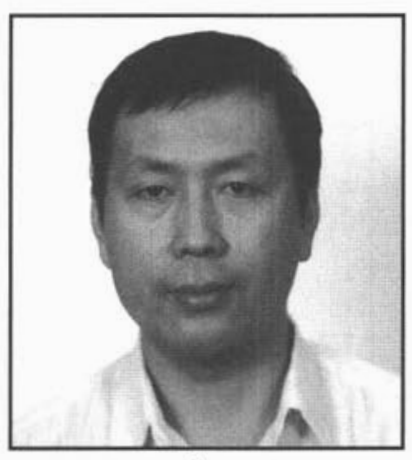

Rongzhou Man

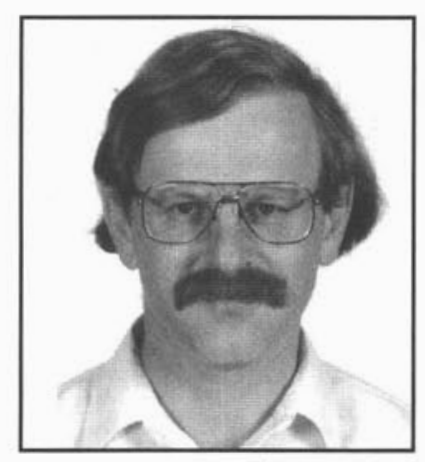

Victor Lieffers the old stand is gradually removed with one or more cuts while simultaneously establishing the next stand of trees under old trees (Smith 1986, Hannah 1988, Waldron and Kolabinski 1994) so that the shelterwood retains some characteristics of understory conditions: cooler daytime temperature, higher relative humidity and lower VPD, lower frequency and severity of night frosts, and less intense irradiance compared to open environments (Childs and Flint 1987, Man and Lieffers 1997). At ground level, environmental conditions of the planting sites can be modified by site preparation (Örlander et al. 1990, Spittlehouse and Childs 1992, Munson et al. 1993, Fleming et al. 1998). In bore- 
al mixedwood forests, mechanical site preparation treatments such as trenching, blading, ploughing, mixing or mounding, are commonly used to reduce competition, raise soil temperature and perhaps stimulate mineralization of nutrients (Lieffers and Beck 1994).

There have been several attempts to apply shelterwood systems and mechanical site preparation to regenerate white spruce in boreal mixedwood sites (Waldron 1959; Lees 1963, 1964, 1970a, 1970b; Youngblood and Zasada 1991) and satisfactory regeneration of white spruce has been produced in white spruce-dominated stands (Waldron and Kolabinski 1994). These shelterwood cuts, however, relied on natural regeneration and lacked thorough investigations of the environmental conditions. It is not clear from these trials how residual density of shelterwood in combination with site preparation affects the regeneration conditions and establishment of planted white spruce.

This study examines the effects of different levels of canopy density and site preparation on such environmental components as light availability (transmission of photosynthetic photon flux density through the overstory canopy) and light quality (Red:Far Red ratio), air temperature and frost occurrence, relative humidity, and soil temperature, and seedling response, including budflush, mortality, photosynthesis and growth of white spruce seedlings in the early period of establishment after planting.

\section{Materials and Methods Site Description}

The study was located in a boreal mixedwood site of Lower Foothills (plant community type is e3.4 Aw-Sw$\mathrm{Pl}$ /prickly rose according to Beckingham et al. 1996), 65 km northwest of Edson, Alberta, Canada $\left(53^{\circ} 42^{\prime} \mathrm{N}, 117^{\circ} 05^{\prime} \mathrm{W}\right)$, with an average slope of about $5 \%$ and an average elevation about $1050 \mathrm{~m}$ above sea level. Climate is subhumid and continental, with long, cold winters and mild summers. Data from the closest weather station (Edson, Alberta) indicate a mean annual precipitation of $568 \mathrm{~mm}$, mean annual temperature of $1.8^{\circ} \mathrm{C}$, and mean temperature of $-11.8^{\circ} \mathrm{C}$ for the coldest month and $14.8^{\circ} \mathrm{C}$ for the warmest month (Environment Canada 1996). The dominant soil type is a Brunisolic Gray Luvisol developed in a thin veneer of loam to sandy loam textured fluvial sediments, underlain by clay loam to clay textured morainal parent material (Proudfoot 1994). Soil $\mathrm{pH}$ ranges from neutral to slightly alkaline (6.5 to 8.0). The organic layer is about $8 \mathrm{~cm}$. Surface drainage is generally good; internal drainage, however, may be somewhat impeded by abrupt textural changes.

Prior to the canopy treatments, the site was covered by a 120year-old mature aspen-white spruce mixedwood, approximately $15-25 \mathrm{~m}^{2} / \mathrm{ha}$ basal area (BA) in aspen (Populus tremuloides Michx.) and 7-15 $\mathrm{m}^{2} /$ ha BA in white spruce with a small amount of balsam poplar (Populus balsamifera L.), black spruce (Picea mariana (Mill.) B.S.P.) and lodgepole pine (Pinus contorta Dougl.). The shrub layer in the control conditions was composed mainly of Rosa acicularis Lindl. and Viburnum edule (Michx.) Raf. Major herbaceous species were Aralia nudicaulis L., Cornus canadensis L., Epilobium angustifolium L., Mertensia paniculata (Ait) G. Don., Pyrola asarifolia Michx. and Rubus pubescens Raf.

\section{Experimental Design and Treatments}

The experiment was a split-plot design, with two replications (blocks), four canopy densities (two shelterwood seeding cuts - low and high residual densities, one uncut control and one conventional clearcut) in the main plots, and three site preparation treatments (blading, mixing and control) in the subplots. Plots for canopy treatments were $150 \mathrm{~m}$ x $150 \mathrm{~m}$; the outer $25 \mathrm{~m}$ served as a buffer leaving a 1 ha area in the centre for sampling. Dominant and codominant leave trees, at the appropriate spacing, were marked prior to cutting. Harvesting was done by feller-buncher in the winter of 1993/1994. Trees were skidded to the landing and processed with a stroke-delimber. Residual basal area was $16.5 \mathrm{~m}^{2} / \mathrm{ha}$ aspen and $3.6 \mathrm{~m}^{2} / \mathrm{ha}$ white spruce in the high residual density of shelterwood (HD), $8.7 \mathrm{~m}^{2} / \mathrm{ha}$ aspen and $3.8 \mathrm{~m}^{2} / \mathrm{ha}$ white spruce in the low residual density of shelterwood (LD), and $18.0 \mathrm{~m}^{2} / \mathrm{ha}$ aspen and $12.5 \mathrm{~m}^{2} /$ ha white spruce in the control (CT). In the early summer of 1994, each canopy treatment plot was subdivided into three 100-m long and 33-m wide subplots for mechanical site preparation. Subplots were bladed, mixed or left untreated (control). Blading removed the organic layer (L, F and $\mathrm{H}$ horizons) and part of the upper mineral soil to a depth of 11 to $13 \mathrm{~cm}$, exposing the eluviated Ae horizon, while in the mixing treatment, the organic layer and top A horizon were mixed to about 10 to $13 \mathrm{~cm}$ depth. Both blading and mixing were done by a Thomas 233 Skidsteer loader fitted with either a hydraulic angle tilt blade $(160 \mathrm{~cm}$ wide) or a MJ MerriCrusher mixing head $(140 \mathrm{~cm}$ wide).

\section{Measurements of Seedling Environments}

Measurements of photosynthetic photon flux density (PPFD) were made on cloudless days at $1.3 \mathrm{~m}$ above the ground between 10:00 and 14:00 solar time in late June 1994, at 15 locations in each site preparation subplot. At each location, 12 readings were taken in an area of about $7 \mathrm{~m}^{2}$ and averaged. Light transmission through the canopy was calculated as a ratio between the average PPFD of each subplot and above canopy PPFD, which was recorded in open locations at the start and finish of light measurements for each subplot.

The Red:Far Red ratio (R:FR, 654-664/724-734 nm) was measured with a portable spectroradiometer (Li-Cor. 1800, Lincoln, NB) between 10:00 and 15:00 solar time on clear days in late June, 1994. Nine locations were sampled at $1.3 \mathrm{~m}$ height in each subplot.

Daily mean, maximum and minimum air temperatures at $0.50 \mathrm{~m}$ above the forest floor were measured in both replicate blocks of the clearcut (CC), HD and CT treatments, using type 101 thermistors (Campbell Scientific Inc., Logan, UT). Relative humidity at $0.50 \mathrm{~m}$ height was measured with a type 201 RH thermistor probe (Campbell Scientific Inc., Logan, UT). Two temperature and one humidity measurement stations from each of the three canopy densities were maintained throughout the growing season of 1995 . All temperature and humidity sensors were suspended in the centre of a horizontal white PVC pipe $(5.0 \mathrm{~cm}$ diameter and $30 \mathrm{~cm}$ long for temperature sensors and $8.0 \mathrm{~cm}$ diameter and $50 \mathrm{~cm}$ long for $\mathrm{RH}$ sensors) to shield them from direct radiation. A number of small $(0.80 \mathrm{~cm}$ diameter $)$ and a few large $(1.40 \mathrm{~cm}$ diameter $)$ holes were drilled at the side and bottom of the pipes to prevent heat and water build-up. Sensors were connected to a datalogger (CR21, Campbell Scientific Inc., Logan, UT) where daily mean, 
maximum, and minimum temperatures and relative humidities were stored.

Five thermocouples (24-gauge copper/constantan) were installed at $0.10 \mathrm{~m}$ depth and three at $0.30 \mathrm{~m}$ depth near the centres of spots for planting seedlings in each site preparation subplot. At each installation, a block of soil was removed to the correct depth and thermocouples were horizontally inserted into the soil before replacing the soil. Instantaneous measurements of soil temperature were made within 2 hours of solar noon on May 5, 19, July 22, August 2, and Sept. 20, 1995 with a microprocessor thermometer (Model HH21, Omega Engineering Inc., Stamford, CT).

\section{Response of Planted Seedlings}

White spruce seeds were collected about $60 \mathrm{~km}$ south of the sites and seedlings were grown at the British Columbia Ministry of Forests nursery in Ladner, BC. One-year-old seedlings raised in PSB 415B styroblock containers $(3.5 \mathrm{~cm}$ diameter, $14.9 \mathrm{~cm}$ depth, and 530 plants $/ \mathrm{m}^{2}$, Beaver Plastic Ltd., Edmonton, Alberta) as summer stock had finished height growth for the current growing season. They had set a bud and stems were hardened, and would not flush until the following spring after planting. These seedlings averaged $18.1 \pm 0.5 \mathrm{~cm}$ (mean \pm standard error) in height and $0.4 \pm 0.1 \mathrm{~cm}$ in root collar diameter when planted on June 21-22, 1994. Ten planting positions were systematically selected in each site preparation subplot and five seedlings were planted at each position. In the blading treatment, seedlings were planted with the entire root plug in mineral soil, whereas in mixing and control site preparation treatments, about a third of the root plug was in mineral soil and the rest was in the mixed or lower organic (LFH) layer.

The following seedling response variables were assessed: bud break of terminals and terminal bud mortality of live seedlings, seedling mortality, gas exchange parameters (net photosynthesis and stomatal conductance), and height and diameter growth of seedlings that were free from damage on the current leader. Bud break of terminals was checked on May 18, May 25, and June 2, 1995 during the first bud break of seedlings after planting. Seedlings with slightly opened scales exposing green foliage were recorded as flushed. Surveys on seedling and terminal bud mortality in subplots were carried out three times, May 18/95, Sept. 25/96, and Sept. 5/97. Height increment was measured for healthy seedlings (no damaged terminal) after terminals were fully extended at the end of each growing season and seedling diameter was measured in the fall of 1997.

Due to time limitations, gas exchange parameters were followed on the seedlings from three canopy densities, CT, HD and $\mathrm{CC}$, and two site preparation treatments, control and blading only. Measurements were taken on May 22, August 18 , and September 25, 1996, the second growing season after planting. The first (spring) measurement was on one-yearold foliage (1995 cohort) while the summer and fall measurements were on current foliage (1996 cohort). All sample shoots were taken from the upper lateral branches. At each sampling date, five seedlings at each subplot were chosen for measurement. Measurements were made in the morning for block one and in the afternoon for block 2 to reduce the effects of variable environmental conditions.

Gas exchange parameters were measured using a portable gas analysis system equipped with a conifer cuvette (LCA-2/PLCC, Analytical Development Corp., Hoddenson, England).
Relative humidity of incoming air was adjusted by using silica gel desiccant so that the relative humidity in the cuvette during measurements was approximately equal to the relative humidity of ambient air. The light source was $12 \mathrm{~V}, 39 \mathrm{~W}$ from a quartz halogen lamp (HR16 SQFL, Philips, NY) positioned on the top of the cuvette to provide photosynthetically saturating light of ca. $1000 \mu \mathrm{mol} \mathrm{m} \mathrm{m}^{-2} \mathrm{~s}^{-1}$. Following gas exchange measurements, the sampled shoots were picked and frozen for later leaf area determinations. Needles were removed form the stems and projected one-sided leaf area was determined using SigmaScan Pro image analysis software (Jandel Scientific, San Rafael, CA) and a ScanJet 4c scanner (Hewlett Packard, Palo Alto, CA) with an image resolution of 3000 dots per inch.

\section{Data Analysis}

Net photosynthesis and stomatal conductance to $\mathrm{H}_{2} \mathrm{O}$ at saturating light were calculated as described by Von Caemmerer and Farquhar (1981).

Analyses of variance were performed on photosynthesis, stomatal conductance and soil temperature, and on accumulated height increment (total height increment in three years) and seedling diameter averaged for each planting position, using the general linear models procedure (PROC GLM) available in SAS Release 6.11 (SAS Institute Inc., 1995). Repeated measurements of photosynthesis and soil temperature over time were treated as a split-split factor as described by Little and Hills (1978). Accumulated height increment and diameter data were excluded in the case that all five seedlings of a planting position were damaged or died. These affects were detected by the analysis of seedling mortality.

Frequency data of bud break, mean terminal bud mortality, and accumulated seedling mortality of each subplot over the three years were analyzed with the categorical data modelling procedure (PROC CATMOD) in SAS. Data were combined across seedling plots within the subplot to produce an adequate sample size. As bud break was just starting on May 18 and was almost completed on June 2, data on May 25 reflected the biggest difference among the treatments and were used for analysis.

\section{Results \\ Microclimate}

Reduction of canopy density increased light transmission and the R:FR ratio (Table 1). The relationship between the light transmission and residual basal area was nearly linear, ranging from $20 \%$ in the uncut stands to $100 \%$ in the clearcut. For the light quality, there was little difference in R:RF ratio between the two shelterwood canopies, LD and HD, but a large difference between the uncut control, the shelterwoods, and the clearcut.

Maximum air temperature and frequency of frost increased and minimum temperature decreased with the reduction of canopy density (Table 1). On average, maximum temperature was about $2.2^{\circ} \mathrm{C}$ warmer in the $\mathrm{HD}$ and $2.7^{\circ} \mathrm{C}$ warmer in the $\mathrm{CC}$ compared to that in the CT. Minimum temperature averaged over the entire growing season was $0.4^{\circ} \mathrm{C}$ lower in the $\mathrm{HD}$ and $2.2^{\circ} \mathrm{C}$ lower in the $\mathrm{CC}$ than that in the CT. Of the 167 days of observations in 1995, 27 night frosts (minimum temperature below $0^{\circ} \mathrm{C}$ ) were recorded in the CT, 28 in the $\mathrm{HD}$, and 49 in the CC. Total number of frosts below $-2^{\circ} \mathrm{C}$ was 11 in the $\mathrm{CT}$, 15 in the $\mathrm{HD}$, and 23 in the CC. The frost-free period includ- 
Table 1. Microclimatic differences between control and treated canopies. Temperature and humidity expressed as the differences between control and treated canopies are averaged from early May to mid-October, 1995, in the second growing season after treatment. Light transmission and R:FR ratio were measured in late June, 1994.

\begin{tabular}{|c|c|c|c|c|}
\hline Canopy density & Control & High residual shelterwood & Low residual shelterwood & Clearcut \\
\hline \multicolumn{5}{|c|}{ Relative temperature $(0.50 \mathrm{~m})$} \\
\hline Maximum & 0.0 & +2.2 & _- & +2.7 \\
\hline Minimum & 0.0 & -0.4 & - & -2.2 \\
\hline \multicolumn{5}{|c|}{ Frost occurrence $(0.50 \mathrm{~m})$} \\
\hline$<0^{\circ} \mathrm{C}$ & 27 & 28 & - & 49 \\
\hline$<-2^{\circ} \mathrm{C}$ & 11 & 15 & - & 23 \\
\hline \multicolumn{5}{|c|}{ Relative RH (0.50 m) } \\
\hline Minimum & 0.0 & -3.5 & - & -7.3 \\
\hline Mean & 0.0 & -2.9 & - & -8.1 \\
\hline \multicolumn{5}{|l|}{ Light $(1.30 \mathrm{~m})$} \\
\hline$\%$ transmission & 20 & 46 & 73 & 100 \\
\hline R:FR ratio & 0.51 & 0.91 & 0.92 & 1.09 \\
\hline
\end{tabular}

ed all of June, July and August, except in the clearcuts where 8 light frosts (minimum temperature between 0 and $-2^{\circ} \mathrm{C}$ ) were recorded during this period.

Relative humidity decreased as canopy density decreased (Table 1). Mean and minimum RH averaged over the whole sampling period was $2.9 \%$ and $3.5 \%$ lower in the $\mathrm{HD}$ and $8.1 \%$ and $7.3 \%$ lower in the CC than those in the CT.

The overall treatment effect on soil temperature was statistically significant only by site preparation treatment $(\mathrm{P}=0.0026$ for $0.10 \mathrm{~m}$ depth and 0.0011 for $0.30 \mathrm{~m}$ ) despite the fact that there was a trend for increased temperature with the reduction of canopy density (Fig. 1). Mean soil temperature at $0.10 \mathrm{~m}$ depth was 1.5 to $3^{\circ} \mathrm{C}$ higher in bladed and mixed treatments than that in the unscarified treatments in the three measurements in spring and early summer (Fig. 1). The difference greatly decreased in August and appeared to be reversed in September, with temperature highest in the control. Similar treatment effects and seasonal patterns existed at deeper soil $(0.30 \mathrm{~m})$ but there were smaller differences among treatments. There was no interaction of canopy density by site preparation treatment at either 0.10 or $0.30 \mathrm{~m}$ depth.

\section{Seedling Response}

Bud break, mean terminal bud mortality, and accumulated seedling mortality after three years were strongly associated with canopy density $(\mathrm{P}<0.0001$ for bud break and mean terminal bud mortality and $\mathrm{P}=0.0038$ for accumulated seedling mortality). On May 25 of 1995 for example, $51.5 \%$ seedlings had flushed under the HD canopy, $45.8 \%$ under the LD canopy, $22.0 \%$ under the CT canopy, and $22.8 \%$ under CC canopies. Mean terminal bud mortality and accumulated seedling mortality showed a similar pattern over the overstory treatments (from CT, HD, LD to CC): $33.0 \%, 7.9 \%, 13.5 \%$, and $17.0 \%$ for terminal mortality and $22.3 \%, 8.3 \%, 9.0 \%$, and $13.3 \%$ for seedling mortality. Most seedling mortality in the clearcut $(7.3 \%)$ occurred before the first growing season (between June 21-22/94 and May 18/95), apparently from water stress while most seedling mortality under the canopy $(11.7 \%$ in the CT, $3.6 \%$ in the $\mathrm{HD}$, and $7.3 \%$ in the LD) occurred in the first growing season after planting from a fungal agent (likely one of the storage moulds of conifer seedlings) (Hiratsuka 1987).

Site preparation treatment had a significant effect only on the accumulated seedling mortality $(\mathrm{P}<0.0001)$. Mean seedling mortality was $7.3 \%$ and $9.0 \%$ for bladed and mixed sites but as high as $23.5 \%$ for the control. None of the interactive effects of canopy density and site preparation was significant except on seedling mortality $(\mathrm{P}=0.0446)$, where scarified sites under partial canopies of shelterwoods had substantially lower mortality than other treatment combinations.

There was a trend for higher net photosynthesis for seedlings growing under a canopy $(\mathrm{P}=0.0358)$ and seedlings on treated (bladed) site conditions ( $\mathrm{P}=0.0983)$, while stomatal conductance was not significantly affected by either canopy density or site preparation despite apparently higher rates for seedlings in the $\mathrm{HD}$ and the CC compared to the CT (Fig. 2). No interactions were significant for either net photosynthesis or stomatal conductance.

At the end of the three years, the total height increment appeared to be weakly affected by canopy density $(\mathrm{P}=0.0574)$ and site preparation $(\mathrm{P}=0.0984)$. Similarly, effects on seedling diameter were nearly significant for canopy density $(\mathrm{P}=0.0511)$ and site preparation $(\mathrm{P}=0.0333)$. Interactions were not significant. For height growth, treatments were ranked (highest to lowest) $\mathrm{LD}, \mathrm{HD}, \mathrm{CC}$, and CT. For seedling diameter the rank was $\mathrm{LD}, \mathrm{CC}, \mathrm{HD}$, and CT (Table 2). Among the three site preparation treatments, both height increment and seedling diameter were highest in the mixing and lowest in the control treatment.

\section{Discussion}

Results from this study suggest that shelterwoods can provide a good compromise in the regeneration environment between the extremes of a clearcut and an intact boreal mixedwood forest. Relative to the intact canopy, the shelterwood increased light transmission from $20 \%$ in the CT to $46 \%$ in the HD and $73 \%$ in the LD, a level that has been shown to produce maximum height growth of young white spruce (Logan 1969, Stiell 1976, Lieffers and Stadt 1994). Diameter growth appeared to benefit from the higher light level in the LD treatment, which is consistent with earlier observations (Eis 1967, Logan 1969, Lieffers and Stadt 1994).

Relative to the clearcut, the shelterwoods had higher humidity, cooler maximum and warmer minimum temperatures, and reduced occurrence and severity of night frost; these are all beneficial to establishing white spruce (Grossnickle and Blake 

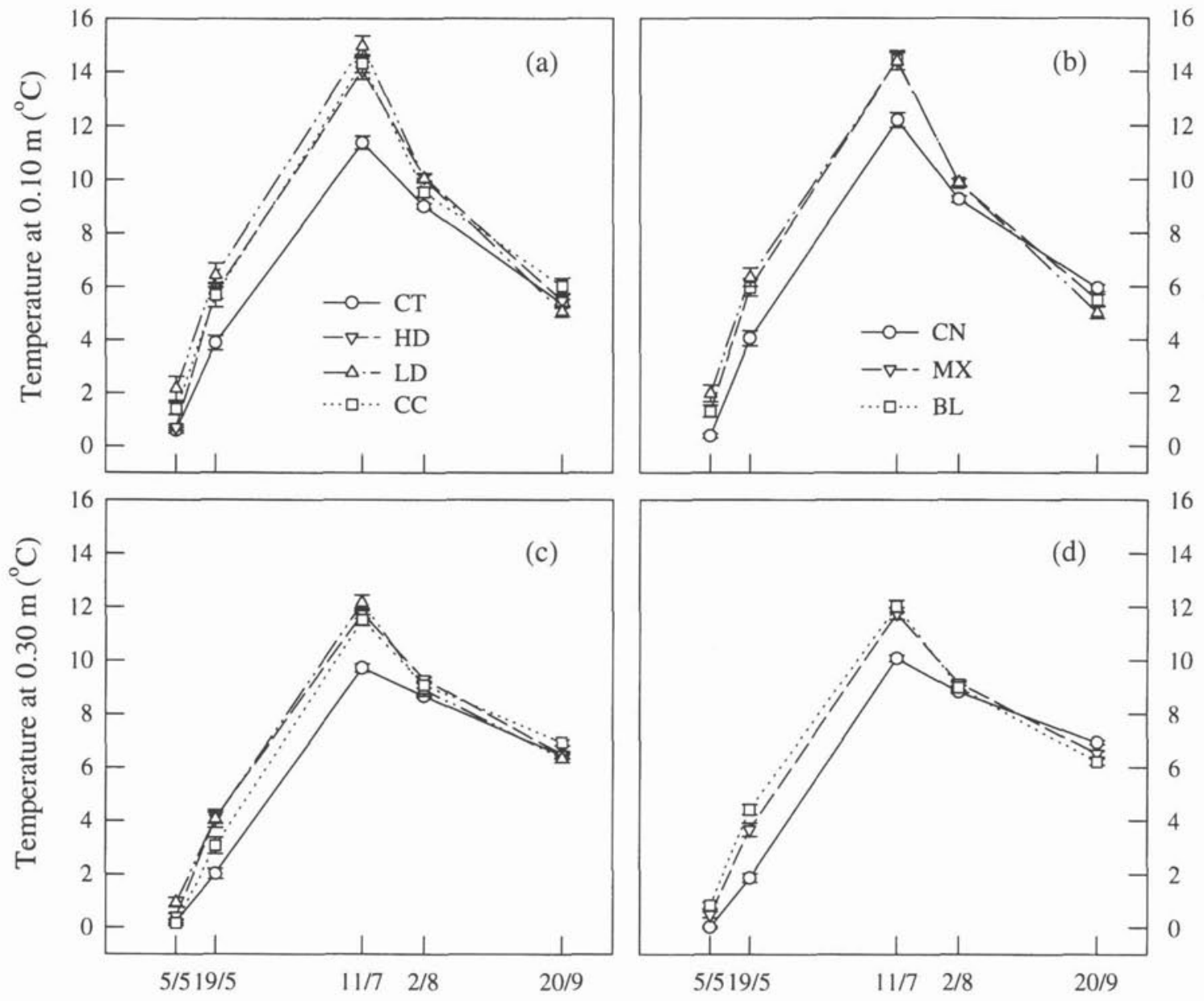

Time (day/month)

Fig. 1. Seasonal soil temperatures (mean \pm SE) at $0.10 \mathrm{~m}(\mathrm{n}=30$ for canopy density and 40 for site preparation) and $0.30 \mathrm{~m}$ ( $\mathrm{n}=18$ for canopy density and 24 for site preparation) depths in relation to canopy (CT-control, HD-high residual density of shelterwood, LD-low residual density of shelterwood, and CC-clearcut) and site preparation (CN-control, MX-mixing, and BL-blading) treatments in 1995.

\begin{tabular}{lcccc}
\hline Table 2. Seedling growth $($ mean \pm SE) & & & \\
\hline Canopy density & Control & High residual shelterwood & Low residual shelterwood & Clearcut \\
\hline Height increment $(\mathrm{cm})$ & $13.91 \pm 0.97$ & $29.00 \pm 0.86$ & $30.77 \pm 0.77$ & $24.40 \pm 1.00$ \\
Total diameter $(\mathrm{mm})$ & $4.99 \pm 0.12$ & $7.46 \pm 0.15$ & $8.07 \pm 0.18$ & \\
& & & Mixing \\
Site preparation & Control & Blading & $26.70 \pm 1.16$ \\
Height increment $(\mathrm{cm})$ & $22.51 \pm 1.00$ & $24.43 \pm 0.99$ & $7.44 \pm 0.22$ \\
Total diameter $(\mathrm{mm})$ & $6.45 \pm 0.17$ & $7.23 \pm 0.18$ & \\
\hline
\end{tabular}

1986, 1987; Colombo and Teng 1992; Groot and Carlson 1996; Marsden et al. 1996). Decreased light transmission and R:FR ratio under partial canopy could reduce photoinhibition (Lundmark and Hällgren 1987, Dang et al. 1992) and increase the resource partitioning to aboveground growth (Ritchie 1997). Man and Lieffers (1997) observed a significant decrease of net photosynthesis in white spruce seedlings planted on open sites compared to seedlings under forest canopy during frost periods in spring and fall. Seedlings under shelterwood canopies showed earlier budbreak, reduced terminal bud and seedling mortality, increased capacity for photosynthesis, and improved growth. All of these suggest that the shelterwood system can be used as an alternative to improve the extreme conditions created by clearcutting and promote white spruce regeneration. 

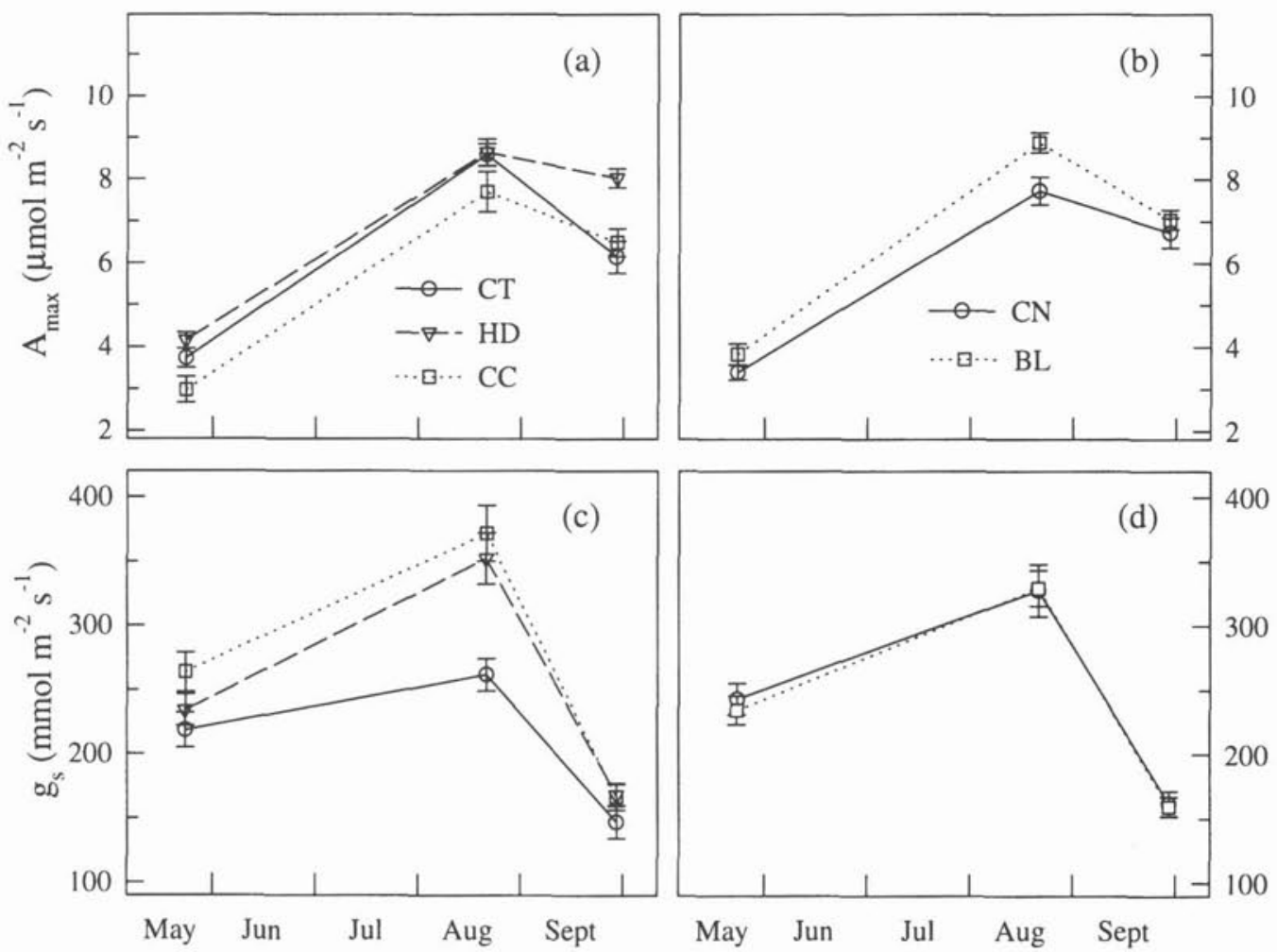

Month (1996)

Fig. 2. Seasonal observations of net photosynthesis $\left(A_{\max }\right)$ and stomatal conductance to $\mathrm{H}_{2} \mathrm{O}\left(\mathrm{g}_{\mathrm{s}}\right)$ of white spruce seedlings $($ mean $\pm \mathrm{SE}, \mathrm{n}=$ 20 for canopy density and 30 for site preparation) after planting in 1996. There were three canopy densities (CT-control, HD-high residual density of shelterwood and CC-clearcut) and two site preparation treatments.

Both terminal bud and accumulated seedling mortality were highest in the CT and lowest in the HD. Two general sources of mortality were observed, environmental extremes-induced mortality (i.e., night frosts, strong radiation, and temporary summer flooding and drought, particularly on the bladed sites in the clearcut), and fungi-induced mortality, which became worse under the closed canopy. The fungal attack on seedlings planted beneath canopies likely originated from nurseryborne fungi. We hypothesize that these fungi were killed in clearcut conditions but the high humidity conditions under the denser canopies, especially the uncut control, allowed their survival. This suggests that extra care is needed to ensure that these fungi are not present on seedlings that are to be underplanted.

Site preparation affected photosynthesis, seedling mortality, and seedling growth likely due to the improved soil conditions. Besides the increased soil temperatures observed in this study, site preparation can also positively influence bulk density, soil moisture, gas exchange in the soil, nutrient availability, and relative humidity and air temperature near the ground surface (Stathers 1989, Örlander et al. 1990, Spittlehouse and Childs 1992, Munson et al. 1993, Fleming et al. 1994), especially immediately following treatment. For the newly planted seedlings, however, improvement in soil moisture condi- tions is probably most critical (Rietveld 1989). Between the site preparation methods used, soil mixing produced greater height and diameter growth than blading treatment, probably due to better water holding capacity and nutrient availability.

Average soil temperatures at both 0.10 and $0.30 \mathrm{~m}$ depths observed in this study were generally lower than the optimum soil temperature for white spruce seedlings (about 15 to $25^{\circ} \mathrm{C}$ ) (Brix 1972, Grossnickle and Blake 1985). Shelterwood treatment reduces overstory density and site preparation reduces the vegetation cover on forest floor, both of which can result in an increase of light received on the ground surface and raise soil temperature. Increased soil temperature has been shown to positively influence water uptake (Teskey et al. 1984), and root growth and photosynthesis of white spruce seedlings (Grossnickle and Blake 1985). As white spruce roots are distributed mostly in upper organic layers of the soil (Strong and La Roi 1983), the increased soil temperature is probably more important to boreal forest species with deeper root systems, such as aspen (Strong and La Roi 1983).

In conclusion, shelterwood and site preparation treatments improved environmental conditions and seedling response of white spruce in the first three years after planting. Under the shelterwood canopy, a residual basal area of 12.5 to $20.1 \mathrm{~m}^{3} / \mathrm{ha}$ 
with a light transmission of 46-73\% appeared to provide adequate protection against environmental extremes according to our direct measurements and seedling response. This is in agreement with the suggestions by Waldron (1966) and Waldron and Kolabinski (1994) for boreal mixedwood stands. Greater seedling growth in the LD and lower terminal bud and seedling mortality in the HD indicate a trade-off between overstory protection and sufficient light for good seedling growth. Further long-term studies, replicated on other sites, are needed to confirm the findings of this study but we feel that the findings of microclimate and seedling response in partial shade of aspen-dominated overstories could be applied to underplanting or other partial-cut silvicultural systems.

\section{Acknowledgements}

The authors want to thank Kent MacDonald, Roger Hayward, Kim Krause, Robert Proudfoot, Rod Sanderson, Susan Hayduk, Dave Kelsberg, and Miranda Hart for their field assistance, Ken Stadt and two reviewers for their constructive criticisms, Peter Blenis for statistical advice and Stan Navratil for discussion. Funding was provided by the Foothills Model Forest and the Natural Science and Engineering Research Council of Canada.

\section{References}

Beckingham, J.D., I.G.W. Corns and J.H. Archibald. 1996. Field guide to ecosites of west-central Alberta. Can. For. Serv, North. Reg., North. For. Cent., Edmonton. Special Rep. 9.

Brix, H. 1972. Growth response of Sitka spruce and white spruce seedlings to temperature and light intensity. Can. For. Serv., Pacific For. Res. Cent., Victoria. Inf. Rep. BC-X-74. 17 p.

Burdett, A.N. 1990. Physiological processes in plantation establishment and the development specifications for forest planting stock. Can. J. For. Res. 20: 415-427.

Burdett, A.N., L.J. Herring and C.F. Thompson. 1984. Early growth of planted spruce. Can. J. For. Res. 14: 644-651.

Childs, S.W. and L.E. Flint. 1987. Effect of shadecards, shelterwoods, and clearcuts on temperature and moisture environments. For. Ecol. Manage. 18: 205-217.

Colombo, S.J. and Y. Teng. 1992. Seasonal variation in the tissue water relations of Picea glauca. Oecologia 92: 410-415.

Dang, Q.L., V.J. Lieffers and R.L. Rothwell. 1992. Effects of summer frosts and subsequent shade on foliage gas exchange in peatland tamarack and black spruce. Can. J. For. Res. 22: 973-979.

Eis, S. 1967. Establishment and early development of white spruce in the interior of British Columbia. For. Chron. 43: 174-177.

Eis, S. 1981. Effect of vegetative competition on regeneration of white spruce. Can. J. For. Res. 11: 1-8.

Environment Canada. 1996. Monthly meteorological summary. Atmospheric Environment Service.

Fleming, R.L., T.A. Black and N.R. Eldridge. 1994. Effects of site preparation on root zone soil water regimes in high-elevation forest clearcuts. For. Ecol. Manage. 68: 173-188.

Fleming, R.L., T.A. Black, R.S. Adams and R.J. Stathers. 1998. Silvicultural treatments, microclimatic conditions and seedling response in Southern Interior clearcuts. Can. J. Soil Sci. 78: 115-125. Groot, A. and D.W. Carlson 1996. Influence of shelter on night temperatures, frost damage, and bud break of white spruce seedlings. Can. J. For. Res. 26: 1531-1538.

Grossnickle, S.C. 1988. Planting stress in newly planted jack pine and white spruce. 1 . Factors influencing water uptake. Tree Physiol. 4: 71-83.

Grossnickle, S.C. and T.J. Blake. 1985. Acclimation of coldstored jack pine and white spruce seedlings: effect of soil temperature on water relation patterns. Can. J. For. Res. 15: 544-550.
Grossnickle, S.C. and T.J. Blake. 1986. Environmental and physiological control of needle conductance for bare-root black spruce, white spruce and jack pine seedlings on boreal cutover sites. Can. J. Bot. 64: 943-949.

Grossnickle, S.C. and T.J. Blake. 1987. Water relations and morphological development of bare-root jack pine and white spruce seedlings: seedling establishment on a boreal cut-over site. For. Ecol. Manage. 18: 299-318.

Hannah, P.R. 1988. The shelterwood method in Northeastern forest types: A literature review. North. J. Appl. For. 5: 70-77.

Hiratsuka, Y. 1987. Forest tree diseases of the prairie provinces. Can. For. Serv., North. For. Cent., Edmonton. Inf. Rep. NOR-X-286. 142 p. Lees, J.C. 1963. Partial cutting with scarification in Alberta spruceaspen stands. Can. Dep. For., For. Res. Br., Ottawa. Publ. 1001. 18 p. Lees, J.C. 1964. A test of harvest cutting methods in Alberta's spruce-aspen forest. Can. Dep. For., For. Res. Br., Ottawa. Publ. 1042. $19 \mathrm{p}$.

Lees, J.C. 1970a. Natural regeneration of white spruce under spruce-aspen shelterwood, B-18a forest section, Alberta. Dep. Fish. For., Can. For. Serv., Ottawa. Publ. 1274. 14 p.

Lees, J.C. 1970b. A test of silvicultural practices designed to secure spruce reproduction in partially cut mixedwood stands in Alberta. Dep. Fish. For., Can. For. Serv., Edmonton. Intern. Rep. A-31. 10 p.

Lieffers, V.J. and J.A. Beck, Jr. 1994. A semi-natural approach to mixedwood management in the prairie provinces. For. Chron. 70: 260-264.

Lieffers, V.J. and K.J. Stadt. 1994. Growth of understory Picea glauca, Calamagrostis canadensis, and Epilobium angustifolium in relation to overstory light transmission. Can. J. For. Res. 24: 1193-1198. Little, T.M. and F.J. Hills. 1978. Agricultural experimentation: Design and analysis. John Wiley and Sons, Inc. 350 p.

Logan, K.T. 1969. Growth of tree seedlings as affected by light intensity. IV. Black spruce, white spruce, balsam fir, and eastern white cedar. Can. For. Serv., Ottawa. Publ. 1256. 12 p.

Lundmark, T. and J.-E. Hällgren. 1987. Effects of frost on shaded and exposed spruce and pine seedlings planted in the field. Can J. For. Res. 17: 1197-1201.

Man, R. and V.J. Lieffers. 1997. Seasonal photosynthetic responses to light and temperature in white spruce (Picea glauca) seedlings planted under an aspen (Populus tremuloides) canopy and in the open. Tree Physiol. 437-444.

Marsden, B.J., V.J. Lieffers and J.J. Zwiazek. 1996. The effect of humidity on photosynthesis and water relations of white spruce seedlings during the early establishment phase. Can. J. For. Res. 26: 1015-1021

Mullin, R.E. 1963. Planting check in spruce. For. Chron. 39: 252-259.

Munson, A.D., H.A. Margolis and D.G. Brand. 1993. Intensive silvicultural treatments: impacts on soil fertility and planted conifer response. Soil Sci. Soc. Am. J. 57: 246-255.

Nienstaedt, H. and J.C. Zasada. 1990. Picea glauca (Moench) Voss. In R.M. Burns and B.H. Honkala (eds.). Silvics of North America, Vol. 1 Conifers. pp. 204-226. USDA Forest Service. Agriculture Handbook $654.675 \mathrm{p}$.

Örlander, G., P. Gemmel and J. Hunt. 1990. Site preparation: a Swedish overview. For. Can. B.C. Minist. For., Victoria. FRDA Rep. 105. $62 \mathrm{p}$.

Proudfoot, R. G. 1994. Soil investigation at shelterwood 1 trial site. Proudfoot and Associates Ltd., Edmonton.

Rietveld, W.J. 1989. Transplanting stress in bareroot conifer seedlings: Its development and progression to establishment. North. J. Appl. For. 6: 99-107.

Ritchie, G.A. 1997. Evidence for red:far red signaling and photomorphogenic growth response in Douglas-fir (Pseudotsuga menziesii) seedlings. Tree Physiol. 17: 161-168.

SAS Institute Inc. 1995. SAS/STAT user's guide, Version 6.11 edition. SAS Institute Inc., Cary, N.C. 
Smith, D.M. 1986. The Practice of Silviculture. Wiley, New York NY. 527 p.

Spittlehouse, D.L. and S.W. Childs. 1992. Evaluating the seedling moisture environment after site preparation. In Sustained Productivity of Forest Soils. 7th N. Am. For. Soils Conf., Vancouver. pp. 80-94. Univ. British Columbia, Fac. For. Publ. 525 p.

Stathers, R.J. 1989. Summer frost in young forest plantations. For. Can. B.C. Min. For., Victoria. FRDA Rep. 073. 24 p.

Stiell, W.M. 1976. White spruce: artificial regeneration in Canada. Environ. Can, Can. For. Serv., For. Manage. Inst., Ottawa. Inf. Rep. FMR-X-85. 275 p.

Strong, W.L. and G.H. La Roi. 1983. Rooting depths and successional development of selected boreal forest communities. Can. J. For. Res. 13: 577-588.

Teskey, R.O., T.M. Hinckley and C.C. Grier. 1984. Temperatureinduced change in the water relations of Abies amabilis (Dougl.) Forbes. Plant Physiol. 74: 77-80.

Von Caemmerer, S. and G.D. Farquhar. 1981. Some relationships between the biochemistry of photosynthesis and the gas exchange of leaves. Planta 153: 376-387.
Vyse, A. 1981. Growth of young spruce plantations in interior British Colombia. For. Chron. 57: 174-180.

Waldron, R.M. 1959. Experimental cutting in a mixedwood stand in Saskatchewan, 1924. Can. Dep. North. Aff. Nat. Res., For. Br., Ottawa. Tech. Note 74.13 p.

Waldron, R.M. 1966. Factors affecting natural white spruce regeneration on prepared seedbeds at the Riding Mountain Forest Experimental area, Manitoba. Can. Dep. For. Rural Devel., For. Br., Ottawa. Publ. 1169. 41 p.

Waldron, R.M. and V.S. Kolabinski. 1994. Uniform shelterwood cutting and scarifying in white spruce-trembling aspen stands to induce natural white spruce regeneration, Manitoba and Saskatchewan. Can. Nat. Res., Can. For. Serv., Winnipeg. Canada-Manitoba. Partnership Agreement in Forestry. 53 p.

Youngblood, A.P. and J.C. Zasada. 1991. White spruce artificial regeneration options on river floodplains in interior Alaska. Can. J. For. Res. 21: 423-433. 